\title{
Identification and Geographic Distribution of Serotypes of Potato Virus Y
}

\author{
P. Ellis, R. Stace-Smith, and G. de Villiers, Phyto Diagnostics Company Limited, 8801 East Saanich Road, \\ Sidney, British Columbia, V8L 1H3, Canada
}

\begin{abstract}
Ellis, P., Stace-Smith, R., and de Villiers, G. 1997. Identification and geographic distribution of serotypes of potato virus Y. Plant Dis. 81:481-484.

From a panel of 10 monoclonal antibodies (MAbs) prepared against specific isolates representing the three recognized strain groups of potato virus $\mathrm{Y}(\mathrm{PVY})$, i.e., common $\left(\mathrm{PVY}^{\mathrm{O}}\right)$, tobacco veinal necrosis $\left(\mathrm{PVY}^{\mathrm{N}}\right)$, and stipple streak $(\mathrm{PVY})$, seven were selected for serotype analysis. These MAbs were tested for reactivity with 52 PVY strains representing all three strain groups from an international collection. Within the PVYN strain group, five serotypes were identified and designated $\mathrm{N}_{1}$ to $\mathrm{N}_{5}$. The $\mathrm{PVY}^{\mathrm{O}}$ strain group was more diverse, and nine serotypes were defined and designated $\mathrm{O}_{1}$ to $\mathrm{O}_{9}$. Only one serotype, designated $\mathrm{C}_{1}$, was defined within the PVYC strain group. The same panel of MAbs was used to test 632 PVY samples collected from potato seed certification plots in North America. Although no PVYN serotypes were found, all of the $\mathrm{PVY}^{\mathrm{O}}$ serotypes were identified, and several samples, tentatively assigned to the $\mathrm{C}_{1}$ serotype, were found.
\end{abstract}

Potato virus Y (PVY) is the type species of the genus Potyvirus (14). PVY has three distinct strain groups, which can be distinguished according to local and systemic symptoms induced on Nicotiana tabacum L. 'White Burley' and 'Samsun NN,'Physalis pubescens L., and several potato (Solanum tuberosum L.) cultivars $(1,3)$. Strain groups are designated common or ordinary strains $\left(\mathrm{PVY}^{\mathrm{O}}\right)$, tobacco veinal necrosis strains $\left(\mathrm{PVY}^{\mathrm{N}}\right)$, and stipple streak strains $\left(\mathrm{PVY}^{\mathrm{C}}\right)$. Strains of $\mathrm{PVY} \mathrm{O}^{\mathrm{O}}$ occur worldwide, but those classified as $\mathrm{PVY}^{\mathrm{N}}$, although prevalent in Europe and South America, are rarely encountered in North America $(10,15)$. Those belonging to the $\mathrm{PVY}^{\mathrm{C}}$ strain group have been reported from Australia, New Zealand, Europe, India, and South Africa (2) but not from North America. Some strains do not belong in any of the three groups $(3,6,7)$. Although serological variability within each group has been observed, there appear to be no consistent serological differences among the groups in tests in which polyclonal antisera are used $(3,5,9)$.

Before strain-specific monoclonal antibodies (MAbs) were available, PVY was diagnosed by using serological procedures based on polyclonal antisera followed by a bioassay. Diagnosis based on serology alone was not considered to be reliable be-

Corresponding author: P. Ellis

E-mail: ellisp@em.agr.ca

Accepted for publication 30 January 1997.

Publication no. D-1997-0319-04R

(C) 1997 The American Phytopathological Society cause of inadequate specificity. The introduction of strain-specific MAbs represented a significant advancement in the detection and diagnosis of the various PVY strains $(5,8,13)$. Despite the improved specificity associated with MAbs, these diagnostic tools have not resolved all of the problems associated with strain designation $(5,16)$. The demonstrated need for more reliable antibodies for PVY strain determination was addressed in a previous study, in which we selected strain-specific MAbs (5). With the panel of MAbs produced previously and others that were commercially available, we were in a position to identify serotypes of PVY. The objectives of this research were to identify serotypes of PVY in an international collection of PVY strains and to determine the occurrence of these serotypes in North American seed potatoes. A preliminary report has been published (4).

\section{MATERIALS AND METHODS}

Sources of reference viral strains. Several PVY strains characterized as belonging to one of the three recognized strain groups and originating from various European countries (Germany, Greece, Hungary, Norway, Spain, Switzerland, and the Netherlands) were obtained from G. Adams (Braunschweig, Germany), and strains originating from Scotland and Ireland were obtained from D. G. Rose (Edinburgh, Scotland). Other strains were obtained from South America (L. Salazar), the United States (G. V. Gooding and R. G. Christie), and Canada (T. L. de Haan, J. G. McDonald, R. P. Singh, and N. S. Wright). A total of 52 strains of PVY were included in serological tests. Most of the PVY strains used in this study were originally isolated from potato ( $S$. tuberosum), although six were from tobacco (N. tabacum) and two were from pepper (Capsicum annuum L.).

Collection of potato samples. In many seed certification programs in North America, seed lots are tested for virus content and quality in winter test nurseries. The winter test sites provide an opportunity to collect samples originating from a large number of locations in Canada and the United States. The plots are located near Homestead, FL, Oceanside, CA, and Kingston, Jamaica. We tested more than 3,000 samples, representing 39 cultivars with origins in seven Canadian provinces and five American states. Leaf and tuber samples were collected from 1991 to 1994 from both symptomatic and asymptomatic plants because some North American potato cultivars show indistinct or no symptoms of $\mathrm{PVY}^{\mathrm{N}}$ infection $(9,16)$.

A quarantine imposed as a result of the discovery of PVY ${ }^{\mathrm{N}}$ in Canada in 1990 has had considerable economic impact on some seed potato programs. For this reason, seed certification officials from some programs were reluctant to provide any samples of PVY. The number of samples that were collected, therefore, was not representative of the total acreage or incidence of virus within any individual seed certification program.

Source of MAbs. Four MAbs from a panel of 10, produced at the Pacific Agriculture Research Center and described previously (5), were selected. Three others, MAb 295.5, described by Rose and Hubbard (12), MAb 4E7 from Ohshima et al. (11), and MAb2, described by McDonald and Kristjansson (9), were used in this study.

Propagation of viral strains. PVY cultures, from the sources described above, were normally provided as dried cultures in tobacco ( $N$. tabacum). These cultures were propagated in $N$. tabacum cv. Samsun by mechanical inoculation in which $0.01 \mathrm{M}$

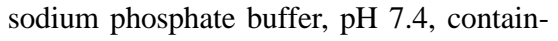
ing 600-mesh Carborundum was used. The inoculated plants were maintained in the greenhouse at $21^{\circ} \mathrm{C}$ for 14 to 21 days before use for either serological testing or purification of the virus.

Indexing of the virus by ELISA. Each of the known viral cultures was tested in tobacco leaf extracts. Leaf tissues, $0.1 \mathrm{~g}$ of virus-infected and virus-free control plants, were ground in a sap extractor (Pollähne, 
Wennigsen, Germany) with $0.9 \mathrm{ml}$ of phosphate buffered saline containing $0.05 \%$ Tween 20 and $0.2 \%$ nonfat milk powder. All of the MAbs except 4E7 were used in an indirect triple-antibody sandwich enzyme-linked immunosorbent assay (TASELISA) as described previously (5). MAb 4E7 was used as an alkaline phosphatase conjugate in double-antibody sandwich (DAS)-ELISA because it lacked viral strain specificity when used in TAS-ELISA (5). The DAS-ELISA procedure was the same as that of TAS-ELISA, except that the alkaline phosphatase-conjugated MAb was used as the detecting antibody. The protocols for both assays were described previously (5). Each test was repeated three times.

The ELISA absorbance values were measured at $405 \mathrm{~nm}$ in a Dynatech MR5000 plate reader (Dynatech Laboratories, Chantilly, VA). ELISA reactions $\left(A_{405}\right)$, after a 4-h incubation of substrate, were considered positive when they were greater than three times the mean of the virus-free control plants.

\section{RESULTS}

Identification of serotypes in an international collection of PVY strains. Only four (295.5, 4E7, 1F5, and 5B9) of the seven MAbs, when used as a panel, were useful for identifying the PVY ${ }^{\mathrm{N}}$ serotypes (Table 1). The other three MAbs did not react with any of the PVY ${ }^{\mathrm{N}}$ strains. Within the $\mathrm{PVY}^{\mathrm{N}}$ strain group, five serotypes were identified and designated $\mathrm{N}_{1}$ to $\mathrm{N}_{5}$. The dominant serotype within this group $\left(\mathrm{N}_{1}\right)$ reacted with all four of the MAbs. Serotypes $\mathrm{N}_{2}$ to $\mathrm{N}_{5}$ were represented by only one or two members of the collection of 25 $\mathrm{PVY}^{\mathrm{N}}$ strains.

The PVY ${ }^{\mathrm{O}}$ strain group was more diverse, and nine serotypes were defined and designated $\mathrm{O}_{1}$ to $\mathrm{O}_{9}$. The pattern of reactivity of five $(295.5,4 \mathrm{E} 7,1 \mathrm{~F} 5,59 \mathrm{H}$, and 5B9) of the seven MAbs was used to identify the nine serotypes (Table 1). One of the remaining two MAbs (MAb2) reacted with all of the $\mathrm{PVY}^{\mathrm{O}}$ strains, and the other $(6 \mathrm{H} 11)$ failed to react with any of them. In contrast to the $\mathrm{PVY}^{\mathrm{N}}$ serotypes, there was no clearly dominant serotype within the $\mathrm{PVY}^{\mathrm{O}}$ strain group. The three most prevalent, $\mathrm{O}_{3}, \mathrm{O}_{6}$, and $\mathrm{O}_{1}$, together accounted for 17 of the $25 \mathrm{PVY}^{\mathrm{O}}$ strains tested. The remaining $\mathrm{PVY}^{\mathrm{O}}$ serotypes were represented by only one or two members.

The two $\mathrm{PVY}^{\mathrm{C}}$ strains that were tested reacted in the same way and were designated serotype $\mathrm{C}_{1}$ (Table 1). Only one $\mathrm{MAb}, 6 \mathrm{H} 11$, was useful for distinguishing this strain group. If MAb $6 \mathrm{H} 11$ was omitted from the test, the $\mathrm{C}_{1}$ serotype could not be distinguished from the $\mathrm{O}_{1}$ serotype.

Geographic origins of serotypes. Of the 52 PVY strains in the international collection, 44 originated from potato $(S$. tuberosum), six from tobacco ( $N$. tabac$u m$ ), and two from pepper (C. annuum). The most common PVY ${ }^{\mathrm{N}}$ serotype $\left(\mathrm{N}_{1}\right)$ was found in samples originating from 10 different countries and was isolated from both tobacco and potato. The other four $\mathrm{PVY}^{\mathrm{N}}$ serotypes were all isolated from potato sources in either Canada, Scotland, or Peru (Table 2). Although the majority of $\mathrm{PVY}^{\mathrm{O}}$ serotypes were isolated from potato, a few were from tobacco and pepper. The most common serotypes $\left(\mathrm{O}_{1}\right.$ to $\left.\mathrm{O}_{3}\right)$ originated from potato and pepper in Australia, Canada, Ireland, Peru, Scotland, Spain, and the United States. Serotypes $\mathrm{O}_{4}$ to $\mathrm{O}_{8}$ were from potato in Canada and the United States, and $\mathrm{O}_{9}$ was from tobacco in South Africa (Table 2). The data on $\mathrm{PVY}^{\mathrm{C}}$ is limited because we were able to obtain

Table 1. Identification of serotypes of the tobacco veinal necrosis strain group $\left(\mathrm{PVY}^{\mathrm{N}}\right)$, the common strain group $\left(\mathrm{PVY}^{\mathrm{O}}\right)$, and the stipple streak strain group $\left(\mathrm{PVY}^{\mathrm{C}}\right)$ based on the reactivity of a panel of seven monoclonal antibodies with 52 potato virus $Y$ strains from an international collection

\begin{tabular}{|c|c|c|c|c|c|c|c|c|}
\hline \multirow{2}{*}{$\begin{array}{l}\text { Group } \\
\text { Serotype }\end{array}$} & \multirow{2}{*}{$\begin{array}{l}\text { No. of } \\
\text { isolates }\end{array}$} & \multicolumn{7}{|c|}{ Reaction with monoclonal antibody ${ }^{a}$} \\
\hline & & 295.5 & $4 \mathrm{E} 7$ & $1 F 5$ & $59 H$ & MAb2 & 5B9 & $6 \mathrm{H11}$ \\
\hline \multicolumn{9}{|l|}{$\mathrm{PVY}^{\mathrm{N}}$} \\
\hline $\mathrm{N}_{1}$ & 20 & + & + & + & - & - & + & - \\
\hline $\mathrm{N}_{2}$ & 2 & - & + & + & - & - & + & - \\
\hline $\mathrm{N}_{3}$ & 1 & - & + & - & - & - & + & - \\
\hline $\mathrm{N}_{4}$ & 1 & + & + & + & - & - & - & - \\
\hline $\mathrm{N}_{5}$ & 1 & + & - & + & - & - & - & - \\
\hline \multicolumn{9}{|l|}{ PVYO } \\
\hline $\mathrm{O}_{1}$ & 8 & - & - & - & + & + & + & - \\
\hline $\mathrm{O}_{2}$ & 5 & - & - & - & - & + & + & - \\
\hline $\mathrm{O}_{3}$ & 4 & - & - & - & + & + & - & - \\
\hline $\mathrm{O}_{4}$ & 2 & - & + & - & + & + & - & - \\
\hline $\mathrm{O}_{5}$ & 2 & - & + & + & + & + & - & - \\
\hline $\mathrm{O}_{6}$ & 1 & - & + & - & + & + & + & - \\
\hline $\mathrm{O}_{7}$ & 1 & + & - & - & - & + & + & - \\
\hline $\mathrm{O}_{8}$ & 1 & - & - & - & - & + & - & - \\
\hline $\mathrm{O}_{9}$ & 1 & - & + & - & - & + & + & - \\
\hline \multicolumn{9}{|l|}{$\mathrm{PVYC}^{\mathrm{C}}$} \\
\hline $\mathrm{C}_{1}$ & 2 & - & - & - & + & + & + & + \\
\hline
\end{tabular}

${ }^{a}$ Reactivity was determined with enzyme-linked immunosorbent assay. Reactions $\left(A_{405}\right)$ after incubation of substrate for $4 \mathrm{~h}$ : $+=>3 \times$ the mean of the virus-free control plants; and $-=<3 \times$ the mean of the virus-free control plants. only two members of this strain group from potato in the Netherlands.

Serotypes of PVY in potato seed samples from Canada and the United States. Of the more than 3,000 seed potato samples indexed, 632 were serologically positive for PVY. This result was not unexpected because the majority of the samples showed no apparent foliar symptoms. None of the field isolates, either symptomatic or asymptomatic, were identified as serotypes belonging to the $\mathrm{PVY}^{\mathrm{N}}$ strain group (Table 3 ). The collection of PVY-positive samples was tested further with the seven MAbs used to define the PVY serotypes.

Most of the isolates were found to belong to the various $\mathrm{PVY}^{\mathrm{O}}$ serotypes (Table 3). Of the nine $P V Y^{O}$ serotypes identified from the international collection of PVY strains, all were found in the field collection from North America. The most common serotype, $\mathrm{O}_{3}$, contained $42 \%$ of all the isolates sampled. This serotype was common in both Canada and the United States and in both eastern and western parts of these countries. Almost $88 \%$ of the common strains belonged to four of the nine defined serotypes.

On the basis of the reactivity of MAb $6 \mathrm{H} 11$, which we found to react only with the two $\mathrm{PVY}^{\mathrm{C}}$ strains in the international collection, we grouped 46 field isolates of PVY into the $\mathrm{C}_{1}$ serotype. However, these isolates showed mosaic symptoms in potato that were typical of common strains of PVY.

\section{DISCUSSION}

Serological reactivity, coupled with biological properties, can be used to differentiate virus strains into groups $(3,5)$. Three strain groups of PVY have been defined and are widely accepted (3). Serological differences among PVY isolates can be used for identifying and differentiating serotypes. Although the distinction between strain and serotype is arbitrary, in this paper we define serotype as any viral strain that is serologically different from a type strain, regardless of whether the difference is large or small (19). A serotype represents a subclass of the viral strain group with distinguishable antigenic specificities. This definition does not apply to cross-reacting isolates that are considered to be members of another strain group on the basis of properties other than serology.

The majority of MAbs used in this study were part of a research project intended to fill the demonstrated need for more reliable diagnostics, particularly relating to the detection of $\mathrm{PVY}^{\mathrm{N}}$ in North America (5). In Canada, a strain of $\mathrm{PVY}^{\mathrm{N}}$ was isolated from tobacco in southern Ontario in 1989. Isolates similar to this strain have been found in potato in subsequent surveys in Prince Edward Island, New Brunswick, Nova Scotia, Quebec, and Ontario (9). To date, $\mathrm{PVY}^{\mathrm{N}}$ has not been found in western Canada (unpublished data). The distribu- 
tion of $\mathrm{PVY}^{\mathrm{N}}$ appears to be restricted in the United States, where it has been reported from both California and Florida (9). Because of the quarantine significance of $\mathrm{PVY}^{\mathrm{N}}$ in North America, regulatory measures have been taken to minimize the risk of spread of this strain group. From the survey of seed potato samples used in the course of this study, it appears these regulatory measures have been successful, since we did not detect $\mathrm{PVY}^{\mathrm{N}}$ in any of the symptomatic or asymptomatic plant samples that were indexed.

The PVYO strain group, named "O" for ordinary strains, has also been described as containing common strains. Common strains induce a severe systemic mosaic on most potato cultivars, systemic necrosis on $P$. pubescens, and a mild systemic mottle in many tobacco cultivars. This group is well named because $\mathrm{PVY} \mathrm{Y}^{\mathrm{O}}$ strains occur worldwide wherever potatoes are grown. The widespread distribution and prevalence of $\mathrm{PVY}^{\mathrm{O}}$ strains provide an increased opportunity for natural selection of wide genetic variability within this strain group. This may explain why we were able to define nine serotypes in the international collection of PVY strains and why all of these serotypes were found among the potato samples we collected from Canada and the United States. We speculate that the wide variation in climatic conditions found in the potato-producing areas of Canada and the United States may select for variation among members of the $\mathrm{PVY}^{\mathrm{O}}$ strain group. Superimposed on environmental and hostselection pressures is the long-distance movement of potato seed and the resulting redistribution of new strains. While certified seed is considered to have much less virus than table stock (17), seed potatoes still represent a potentially important source of new viral strains.

Members of the $\mathrm{PVY}^{\mathrm{N}}$ strain group are more restricted in their geographic distribution than those of the $\mathrm{PVY}^{\mathrm{O}}$ strain group, which occur wherever potatoes are grown (3). This may explain why we distinguished only five serotypes in the $\mathrm{PVY}^{\mathrm{N}}$ strain group but nine in the $\mathrm{PVY}^{\mathrm{O}}$ strain group.

The $\mathrm{PVY}^{\mathrm{C}}$ strain group is more restricted in its distribution than either of the other two strain groups, and the characterization of members of this group is ambiguous. Many potato cultivars are hypersensitive to strains of $\mathrm{PVY}^{\mathrm{C}}$ (3), and some strains of $\mathrm{PVY}^{\mathrm{C}}$ are not aphid transmissible, two factors that limit the distribution of these strains in potato. One isolate from the Netherlands and one from Ireland did not react with PVY antiserum but did react with antiserum produced against a virus isolate from central Peru (6). This suggests that some virus isolates previously placed in the $\mathrm{PVY}^{\mathrm{C}}$ strain group do not belong to any of the established PVY strain groups.

The results from this study are too limited to draw any conclusions about sero- logical variability within the $\mathrm{PVY}^{\mathrm{C}}$ strain group. While the $C_{1}$ serotype has not previously been reported from North America, we found it in 46 samples from both Canada and the United States. It must be recognized that our identification of this serotype is based on a single epitope that reacts with MAb 6H11. This MAb appears to be specific for $\mathrm{PVY}^{\mathrm{C}}$ in that it does not react with any of the $\mathrm{PVY}^{\mathrm{O}}$ or $\mathrm{PVY}^{\mathrm{N}}$ strains included in our study. However, symptoms in the 46 samples identified as caused by the $C_{1}$ serotype were indistinguishable from the symptoms induced by the serotypes of the common strains in samples collected in the field plots. While our evidence is limited, we feel it would be reasonable to include the $\mathrm{C}_{1}$ serotype as another serotype of $\mathrm{PVY}^{\mathrm{O}}$. However, we hesitate at this time to classify $\mathrm{C}_{1}$ as a serotype within the common strain group until a larger international collection of $\mathrm{PVY}^{\mathrm{C}}$ strains can be tested.

An additional benefit of this study is that we have identified the distribution of PVY serotypes in Canada and the United States

Table 2. Geographic sources and original hosts of the five serotypes of the tobacco veinal necrosis strain of potato virus $\mathrm{Y}\left(\mathrm{PVY} \mathrm{Y}^{\mathrm{N}}\right)$, the nine of the common strain group (PVYO), and one of the stipplestreak strain group $\left(\mathrm{PVY}^{\mathrm{C}}\right)$

\begin{tabular}{|c|c|c|}
\hline $\begin{array}{l}\text { Serotype } \\
\text { Strain }\end{array}$ & Origin $^{a}$ & Host plant \\
\hline \multicolumn{3}{|l|}{ PVYN } \\
\hline \multirow[t]{3}{*}{$\mathrm{N}_{1}$} & Canada (PE, QC, NB) & Solanum tuberosum \\
\hline & Canada $(\mathrm{ON})$, Hungary & Nicotiana tabacum \\
\hline & $\begin{array}{l}\text { Germany, Greece, Ireland, the Netherlands, New Zealand, } \\
\text { Norway, Switzerland, United States (CA, FL) }\end{array}$ & S. tuberosum \\
\hline \multirow[t]{2}{*}{$\mathrm{N}_{2}$} & Canada (NB) & S. tuberosum \\
\hline & Canada (ON) & N. tabacum \\
\hline $\mathrm{N}_{3}$ & Canada (ON) & S. tuberosum \\
\hline $\mathrm{N}_{4}$ & Scotland & S. tuberosum \\
\hline $\mathrm{N}_{5}$ & Peru & S. tuberosum \\
\hline \multicolumn{3}{|l|}{ PVY } \\
\hline \multirow[t]{3}{*}{$\mathrm{O}_{1}$} & Australia, Scotland & S. tuberosum \\
\hline & Hungary, United States (NC) & N. tabacum \\
\hline & Spain & Capsicum annuum \\
\hline \multirow[t]{3}{*}{$\mathrm{O}_{2}$} & Scotland & S. tuberosum \\
\hline & United States (NC) & N. tabacum \\
\hline & Australia, Spain & C. annuum \\
\hline \multirow[t]{2}{*}{$\mathrm{O}_{3}$} & Canada (BC), Ireland, Peru & S. tuberosum \\
\hline & Australia & N. tabacum \\
\hline $\mathrm{O}_{4}$ & Canada (NB), United States (ME) & S. tuberosum \\
\hline $\mathrm{O}_{5}$ & Canada (NB, PE) & S. tuberosum \\
\hline $\mathrm{O}_{6}$ & United States (ME) & S. tuberosum \\
\hline $\mathrm{O}_{7}$ & Canada (NB) & S. tuberosum \\
\hline $\mathrm{O}_{8}$ & Canada (NB) & S. tuberosum \\
\hline $\mathrm{O}_{9}^{\circ}$ & South Africa & N. tabacum \\
\hline \multicolumn{3}{|l|}{$\mathrm{PVY}^{\mathrm{C}}$} \\
\hline $\mathrm{C}_{1}$ & The Netherlands & S. tuberosum \\
\hline
\end{tabular}

${ }^{\mathrm{a}} \mathrm{BC}=$ British Columbia; $\mathrm{CA}=$ California; $\mathrm{FL}=$ Florida; $\mathrm{ME}=$ Maine $; \mathrm{NB}=$ New Brunswick; NC = North Carolina; $\mathrm{ON}=$ Ontario; $\mathrm{PE}=$ Prince Edward Island; and QC $=$ Quebec.

Table 3. Identification of potato virus Y (PVY) serotypes in 632 seed potato samples from Canada and the United States

\begin{tabular}{|c|c|c|c|c|c|c|c|c|c|c|c|}
\hline \multirow[b]{2}{*}{ Origin } & \multicolumn{11}{|c|}{ Number of isolates in each serotype ${ }^{a}$} \\
\hline & $\mathbf{N}_{1-5}$ & $\mathbf{O}_{1}$ & $\mathbf{O}_{2}$ & $\mathbf{O}_{3}$ & $\mathbf{O}_{4}$ & $\mathbf{O}_{5}$ & $\mathbf{O}_{6}$ & $\mathbf{O}_{7}$ & $\mathbf{O}_{8}$ & $\mathbf{O}_{9}$ & $\mathbf{C}_{1}$ \\
\hline \multicolumn{12}{|l|}{ Canada } \\
\hline British Columbia & 0 & 4 & 0 & 14 & 0 & 0 & 27 & 1 & 0 & 0 & 1 \\
\hline Manitoba & 0 & 2 & 0 & 7 & 6 & 4 & 3 & 1 & 0 & 0 & 0 \\
\hline New Brunswick & 0 & 8 & 0 & 82 & 3 & 2 & 1 & 10 & 7 & 5 & 18 \\
\hline Nova Scotia & 0 & 0 & 0 & 2 & 0 & 0 & 0 & 3 & 0 & 0 & 2 \\
\hline Ontario & 0 & 0 & 0 & 0 & 0 & 0 & 0 & 1 & 0 & 0 & 0 \\
\hline Prince Edward Island & 0 & 1 & 0 & 57 & 0 & 0 & 0 & 16 & 4 & 1 & 21 \\
\hline Quebec & 0 & 0 & 0 & 1 & 0 & 0 & 0 & 0 & 0 & 1 & 0 \\
\hline \multicolumn{12}{|l|}{ United States } \\
\hline California & 0 & 0 & 0 & 2 & 1 & 0 & 0 & 0 & 0 & 0 & 0 \\
\hline Colorado & 0 & 0 & 0 & 6 & 1 & 0 & 0 & 1 & 0 & 0 & 0 \\
\hline Idaho & 0 & 58 & 15 & 94 & 11 & 2 & 86 & 21 & 2 & 3 & 2 \\
\hline Maine & 0 & 4 & 0 & 1 & 0 & 0 & 0 & 0 & 0 & 0 & 2 \\
\hline Wisconsin & 0 & 2 & 0 & 2 & 0 & 0 & 0 & 0 & 0 & 0 & 0 \\
\hline Total & 0 & 79 & 15 & 268 & 22 & 8 & 117 & 54 & 19 & 10 & 46 \\
\hline
\end{tabular}

a Number of PVY isolates collected does not reflect the incidence of PVY in the seed lots from the different locations. Some seed potato program managers were reluctant to provide samples. 
in advance of the commercial release of PVY-resistant transgenic potato cultivars. Some transgenic lines show resistance that is near immunity, whereas others accumulate less virus than nontransformed lines (18). Since most transgenic lines have only one gene for resistance, usually the virus coat protein gene (20), they will undoubtedly exert new selection pressures on the naturally occurring populations of PVY when they are released in commercial production. The panel of MAbs we have described here may be used in the future to study the possibility of changes in the serotypes of PVY that occur in potato after the release of PVY-resistant transgenic potato cultivars. It is possible that some of the serotypes that are common now will become less prevalent or disappear and that new ones will arise.

\section{LITERATURE CITED}

1. Barnett, O. W. 1992. A summary of potyvirus taxonomy and definitions. Pages 435-444 in: Potyvirus Taxonomy. O. W. Barnett, ed. Springer Verlag, New York.

2. d'Aquino, L., Dalmay, T., Burgyán, J., Ragozzino, A., and Scala, F. 1995. Host range and sequence analysis of an isolate of potato virus $\mathrm{Y}$ inducing veinal necrosis in pepper. Plant Dis. 79:1046-1050.

3. de Bokx, J. A., and Huttinga, H. 1981. Potato virus Y. No. 242 in: Descriptions of Plant
Viruses. Commonw. Mycol. Inst./Assoc. Appl. Biol., Kew, England.

4. Ellis, P., Stace-Smith, R., and Bowler, G. 1995. Geographic distribution of serotypes of potato virus Y. (Abstr.) Phytopathology 85: 1039.

5. Ellis, P., Stace-Smith, R., Bowler, G., and MacKenzie, D. J. 1996. Production of monoclonal antibodies for detection and identification of strains of potato virus Y. Can. J. Plant Pathol. 18:64-70.

6. Fribourg, C. E., and Nakashima, J. 1984. Characterization of a new potyvirus from potato. Phytopathology 74:1363-1369.

7. Gooding, G. V., Jr., and Tolin, S. A. 1973. Strains of potato virus $\mathrm{Y}$ affecting flue-cured tobacco in the southeastern United States. Plant Dis. Rep. 57:200-204.

8. Gugerli, P., and Fries, P. 1983. Characterization of monoclonal antibodies to potato virus $\mathrm{Y}$ and their use for virus detection. J. Gen. Virol. 64:2471-2477.

9. McDonald, J. G., and Kristjansson, G. T. 1993. Properties of strains of potato virus $\mathrm{Y}^{\mathrm{N}}$ in North America. Plant Dis. 77:87-89.

10. McDonald, J. G., Kristjansson, G. T., Singh, R.P., Ellis, P. J., and McNab, W. B. 1994. Consecutive ELISA screening with monoclonal antibodies to detect potato virus $\mathrm{Y}^{\mathrm{N}}$. Am. Potato J. 71:175-183.

11. Ohshima, K., Inoue, A. K., Ishikawa, Y., Shikata, E., and Hagita, T. 1990. Production and application of monoclonal antibodies specific to ordinary strain and necrotic strain of potato virus Y. Ann. Phytopathol. Soc. Jpn. 56:508-514.

12. Rose, D. G., and Hubbard, A. L. 1983.
Production of monoclonal antibodies for the detection of potato virus Y. Ann. Appl. Biol. 109:317-321.

13. Rose, D. G., McCarra, S., and Mitchell, D. H 1987. Diagnosis of potato virus $\mathrm{Y}^{\mathrm{N}}$ : A comparison between polyclonal and monoclonal antibodies and a biological assay. Plant Pathol. 36:95-99.

14. Shukla, D. D. 1994. The Potyviridae. D. D. Shukla, C. W. Ward, and A. A. Brunt, eds. C.A.B. International, Orion, England.

15. Singh, R. P. 1992. Incidence of the tobacco veinal necrotic strain of potato virus Y $\left(\mathrm{PVY}^{\mathrm{N}}\right)$ in Canada in 1990 and 1991 and scientific basis for eradication of the disease. Can. Plant Dis. Surv. 72:113-119.

16. Singh, R. P., Boucher, A., Somerville, T. H. and Dhar, A. K. 1993. Selection of a monoclonal antibody to detect PVY ${ }^{\mathrm{N}}$ and its use in ELISA and DIBA assays. Can. J. Plant Pathol. 15:293-300.

17. Slack, S. A. 1993. Seed certification and seed improvement programs. Pages 61-65 in: Potato Health Management. R. C. Rowe, ed. American Phytopathological Society, St. Paul, MN.

18. Smith, H. A., Powers, H., Swaney, S., Brown, C., and Dougherty, W. G. 1995. Transgenic potato virus $\mathrm{Y}$ resistance in potato: Evidence for an RNA-mediated cellular response. Phytopathology 85:864-870.

19. Van Regenmortel, M. H. V. 1982. Serology and Immunochemistry of Plant Viruses. Academic Press, New York.

20. Wilson, T. M. A. 1993. Strategies to protect crop plants against viruses: Pathogen-derived resistance blossoms. Proc. Natl. Acad. Sci USA 90:3134-3141. 